\title{
ANALISIS RISIKO KEKERINGAN DI KABUPATEN BANTUL PROVINSI D.I. YOGYAKARTA
}

\author{
Annisa Mu'awanah Sukmawati ${ }^{1}$ \\ Puji Utomo ${ }^{2}$ \\ ${ }^{1}$ Program Studi Perencanaan Wilayah dan Kota, Fakultas Sains dan Teknologi, Universitas Teknologi \\ Yogyakarta; \\ ${ }^{2}$ Program Studi Teknik Sipil, Fakultas Sains dan Teknologi, Universitas Teknologi Yogyakarta \\ ${ }^{1}$ Penulis Korespondensi e-mail: annisa.sukmawati@staff.uty.ac.id
}

\begin{abstract}
Bantul Regency is a district in Yogyakarta Province which has geographic, geological, hydrological, and demographic characteristics that are likely to cause drought. Drought event in Bantul Regency may have significant impacts on various aspects in line with the characteristics of drought impacts which are complex and cross-sectoral. This study addresses to analyze the level of risk of drought with observation units in 75 villages in the Bantul Regency. The risk analysis was carried out by comparing the time period of the 10 years, i.e. 2008 and 2018 to observe the shift of risk areas of drought in Bantul Regency. The research was conducted using quantitative research methods with quantitative descriptive and mapping analysis. The analysis steps are drought hazard analysis, vulnerability analysis, and drought risk analysis. The analysis shows that during the last 10 years, Kabupaten Bantul has been experiencing an increasing number of villages classified as high risk of drought, both in urban and rural areas. In 2008 there were 15 villages (20\%) and increased to 21 villages (28\%) in 2018 that were classified as very very high level. Meanwhile, in 2008 there were 30 villages (40\%) in 2008 and increased to 32 villages (42.7\%) in 2018 that were classified as very high level. It caused by the increasing probability of drought as well as vulnerability. The analysis results can be used as input for stakeholders to take mitigation and anticipation actions to reduce the impact of drought based on the spatial characteristics of the risk areas.
\end{abstract}

Keywords: Drought Hazard, Bantul Regency, Risk

\begin{abstract}
ABSTRAK
Kabupaten Bantul adalah kabupaten di Provinsi DIY yang memiliki karakteristik geografis, geologis, hidrologis, dan demografis yang berpeluang menjadi penyebab bencana kekeringan. Kekeringan yang terjadi di Kabupaten Bantul dapat menimbulkan dampak signifikan bagi berbagai aspek sejalan dengan dampak kekeringan yang bersifat kompleks dan lintas sektor. Penelitian bertujuan untuk menganalisis tingkat risiko bahaya kekeringan dengan unit amatan pada 75 desa di Kabupaten Bantul. Analisis risiko dilakukan dengan membandingkan periode waktu 10 tahun, yaitu tahun 2008 dan 2018 untuk melihat perkembangan wilayah yang berisiko kekeringan di Kabupaten Bantul. Penelitian dilakukan dengan metode penelitian kuantitatif dengan teknik analisis deskriptif kuantitatif dan pemetaan. Langkah-langkah analisis yang dilakukan meliputi analisis bahaya kekeringan, analisis kerentanan, dan analisis risiko kekeringan. Hasil analisis menunjukkan bahwa selama 10 tahun terakhir terdapat peningkatan jumlah desa yang tergolong berisiko tinggi terhadap kekeringan, baik di kawasan perkotaan dan perdesaan. Pada tahun 2008 terdapat 15 desa (20\%) yang tergolong sangat sangat tinggi dan meningkat menjadi 21 desa (28\%) pada tahun 2018. Sementara itu, untuk kategori sangat tinggi meningkat dari sejumlah 30 desa (40\%) di tahun 2008 dan bertambah menjadi 32 desa $(42,7 \%)$ pada tahun 2018. Hal ini disebabkan oleh semakin meningkatnya peluang terjadinya bahaya kekeringan maupun kondisi kerentanan yang semakin tinggi. Hasil analisis dapat menjadi masukkan bagi para pemangku kepentingan untuk melakukan mitigasi dan antisipasi guna mengurangi dampak kekeringan berdasarkan karakteristik wilayah yang berisiko.

Kata kunci: Bahaya Kekeringan, Kabupaten Bantul, Risiko
\end{abstract}




\section{PENDAHULUAN}

Indonesia merupakan negara tropis yang memiliki dua musim, yaitu musim penghujan dan kemarau. Permasalahan yang sering muncul di musim penghujan adalah bencana banjir. Sementara itu, bencana kekeringan kerap terjadi pada musim kemarau di berbagai wilayah Indonesia. Data Badan Nasional Penanggulangan Bencana Indonesia tahun 2019 menunjukkan bahwa bencana kekeringan menempati urutan ketiga sebagai bencana yang paling sering terjadi di Indonesia setelah bencana kebakaran hutan dan lahan serta puting beliung dengan jumlah kejadian 1.529 kali dari total 9.375 kejadian seluruh bencana di Indonesia (BNPB Indonesia, 2019). Hal ini menjadikan bencana kekeringan merupakan salah satu bencana yang perlu diperhatikan dan diantisipasi oleh seluruh pemangku kepentingan.

Hasil pemantauan Badan Meteorologi Klimatologi dan Geofisika (BMKG) sejak akhir tahun 2018 hingga akhir tahun 2019, beberapa wilayah di Indonesia mengalami kekeringan panjang dengan persentase sekitar 92\%. Hal ini disebabkan oleh fenomena El-Nino yang menjadikan musim kemarau menjadi lebih kering (CNN Indonesia, 2019; Nuarsa et al., 2015).

Bencana kekeringan terus meningkat besarannya (magnitude), baik intensitas, periode ulang, dan lamanya akibat pemanasan global. Beberapa penelitian menunjukkan bahwa perubahan iklim memperparah terjadinya bencana kekeringan karena berakibat pada semakin meluasnya dampak yang ditimbulkan pada berbagai sektor (Fontaine \& Steinemann, 2009; Kim et al., 2015; Liang et al., 2019; Nam et al., 2015; Yuan et al., 2013). Perubahan iklim mengakibatkan naiknya temperatur dan curah hujan yang ekstrim yang mengubah frekuensi dan durasi bencana kekeringan (Nam et al., 2015).

Secara umum, kekeringan didefinisikan sebagai periode masa kering yang lebih lama dari kondisi normal dan menyebabkan ketersediaan air yang jauh di bawah kebutuhan air (Hisdal \& Tallaksen, 2000; Nagarajan, 2009). Kekeringan merupakan kejadian yang bersifat natural terkait dengan rendahnya curah hujan pada kurun waktu bulanan hingga tahunan (Dai, 2011; Rahman \& Lateh, 2016). Kekeringan dapat diklasifikasikan menjadi empat jenis, yaitu kekeringan meteorologis, kekeringan pertanian, kekeringan hidrologi, dan kekeringan sosialekonomi (Wilhite \& Glantz, 1985). Kekeringan meteorologis sering digunakan sebagai indikasi pertama bencana kekeringan. Ini dikarenakan kekeringan meteorologis, yang terkait dengan rendahnya presipitasi air, menjadi penyebab utama kekeringan. Dalam analisis bahaya kekeringan juga seringkali digunakan data curah hujan yang mana data tersebut merupakan 
data terkait dengan kekeringan meteorologis. Sementara itu, jenis kekeringan lainnya merupakan manifestasi dari kekeringan meteorologis (Hisdal \& Tallaksen, 2000).

Beberapa penelitian menunjukkan bahwa kekeringan dapat menimbulkan dampak yang luas, kompleks, bersifat lintas sektor (ekonomi, sosial, kesehatan, dan pendidikan), dan memiliki rentang waktu yang panjang. Ini dikarenakan air merupakan kebutuhan pokok dan vital bagi seluruh makhluk hidup yang tidak dapat digantikan dengan sumber daya lainnya. Kekeringan dapat mempengaruhi keberlangsungan hidup manusia, sistem lingkungan (natural system), sosial ekonomi, ketersediaan air dan pangan, pertanian, dan lainnya (Bin et al., 2011; Kim et al., 2015; Nasrollahi et al., 2018; Rahman \& Lateh, 2016). Pertambahan populasi, urbanisasi, dan peningkatan ekonomi akan meningkatkan kebutuhan air. Di sisi lain, hal ini juga menyebabkan hilangnya ketersediaan air yang berpotensi menyebabkan kekeringan dan kelangkaan air (Kim et al., 2015; Shahid \& Behrawan, 2008; Yuan et al., 2013).

Meskipun memiliki dampak yang paling besar dibanding bencana lainnya, bencana kekeringan belum banyak mendapatkan perhatian berbagai pihak, baik pada konteks nasional maupun global (Dabanli, 2018; Kim et al., 2015; Nam et al., 2015; Shahid \& Behrawan, 2008; Hastuti et al., 2017). Diperlukan kesiapsiagaan untuk meminimalisir risiko bencana kekeringan serta langkah adaptasi untuk meningkatkan ketahanan terhadap bencana.

Menilai risiko bencana kekeringan perlu dilakukan sebagai upaya telaah awal mengenai sebaran spasial wilayah berisiko kekeringan. Menilai risiko bencana merupakan langkah awal dari upaya pengurangan risiko bencana. Ini dikarenakan penilaian risiko tidak hanya melihat kemungkinan kerugian dan dampak yang ditimbulkan, namun juga memperhitungkan tingkat risiko menurut level kerugiannya (Dickson et al., 2012). Secara definisi, risiko merupakan integrasi dua fungsi, yaitu bahaya yang ditimbulkan dan derajat kerentanan (Wisner et al., 2005). Wisner et al. (2005) menjelaskan bahwa risiko memiliki tiga komponen, yaitu fungsi keterpaparan (Exposure), kerentanan (Vulnerability), dan kapasitas adaptasi (Adaptive Capacity). Namun, hanya sedikit studi yang menilai risiko kekeringan secara komprehensif dengan mengintegrasikan indeks bencana kekeringan (drought hazard index) dan kerentanan kekeringan (drought vulnerability index) serta menampilkan hasilnya secara spasial (Dabanli, 2018; Nasrollahi et al., 2018; Shahid \& Behrawan, 2008).

Kabupaten Bantul adalah kabupaten di Provinsi DIY yang memiliki karakteristik geografis, geologis, hidrologis, dan demografis yang berpeluang menjadi penyebab 
bencana kekeringan. Berdasarkan data Badan Penanggulangan Bencana Daerah (BPPD) Kabupaten Bantul tahun 2017 terdapat 8 kecamatan dan 19 desa rawan kekeringan. Sementara itu, wilayah yang berpotensi mengalami kekeringan dengan status siaga pada akhir tahun 2018 hingga Agustus 2019 terdapat di 6 kecamatan dan 15 desa. Lebih lanjut, diperkirakan sekitar 50.000 jiwa berpeluang mengalami dampak kekeringan (Christiyaningsih, 2019). Di sisi lain, kekeringan di Kabupaten Bantul juga dapat menimbulkan dampak signifikan bagi sektor pertanian. Kabupaten Bantul adalah salah satu wilayah sentra pertanian Provinsi D.I. Yogyakarta. Proporsi lahan pertanian di Kabupaten Bantul tercatat hampir mencapai 30\% dari total wilayahnya (BPS Kabupaten Bantul, 2018). Hasil penelitian Purnamawati (2014) juga menunjukkan bahwa 87\% wilayah di Kabupaten Bantul memiliki kerawanan kekeringan tingkat sedang untuk lahan pertanian jenis tanaman pangan. Kondisi ini akan memengaruhi produksi pertanian skala regional serta berdampak bagi sosial ekonomi karena masyarakat perlu mengeluarkan biaya lebih untuk memperoleh air bersih.

Penelitian ini bertujuan untuk menganalisis tingkat risiko bencana kekeringan di Kabupaten Bantul. Unit amatan penelitian adalah 75 desa di Kabupaten Bantul. Analisis risiko perlu dilakukan sebagai langkah awal mitigasi untuk mengurangi dampak kekeringan dengan melihat sebaran lokasi yang berisiko terhadap kekeringan untuk selanjutnya dapat diberikan intervensi kebijakan. Analisis risiko dilakukan dengan membandingkan periode waktu 10 tahun terakhir, yaitu tahun 2008 dan 2018 untuk melihat perkembangan wilayah yang berisiko kekeringan di Kabupaten Bantul.

\section{METODOLOGI}

Penelitian dilakukan dengan metode penelitian kuantitatif karena penelitian bertujuan untuk menilai tingkat risiko bencana kekeringan yang terjadi di Kabupaten Bantul. Tahapan analisis yang dilakukan meliputi 1) Menilai tingkat bencana kekeringan, 2) Menilai tingkat kerentanan bencana kekeringan, dan 3) Menilai tingkat risiko bencana kekeringan. Analisis dilakukan dengan menggunakan teknik analisis deskriptif kuantitatif dan didukung oleh analisis pemetaan untuk melihat sebaran spasial. 


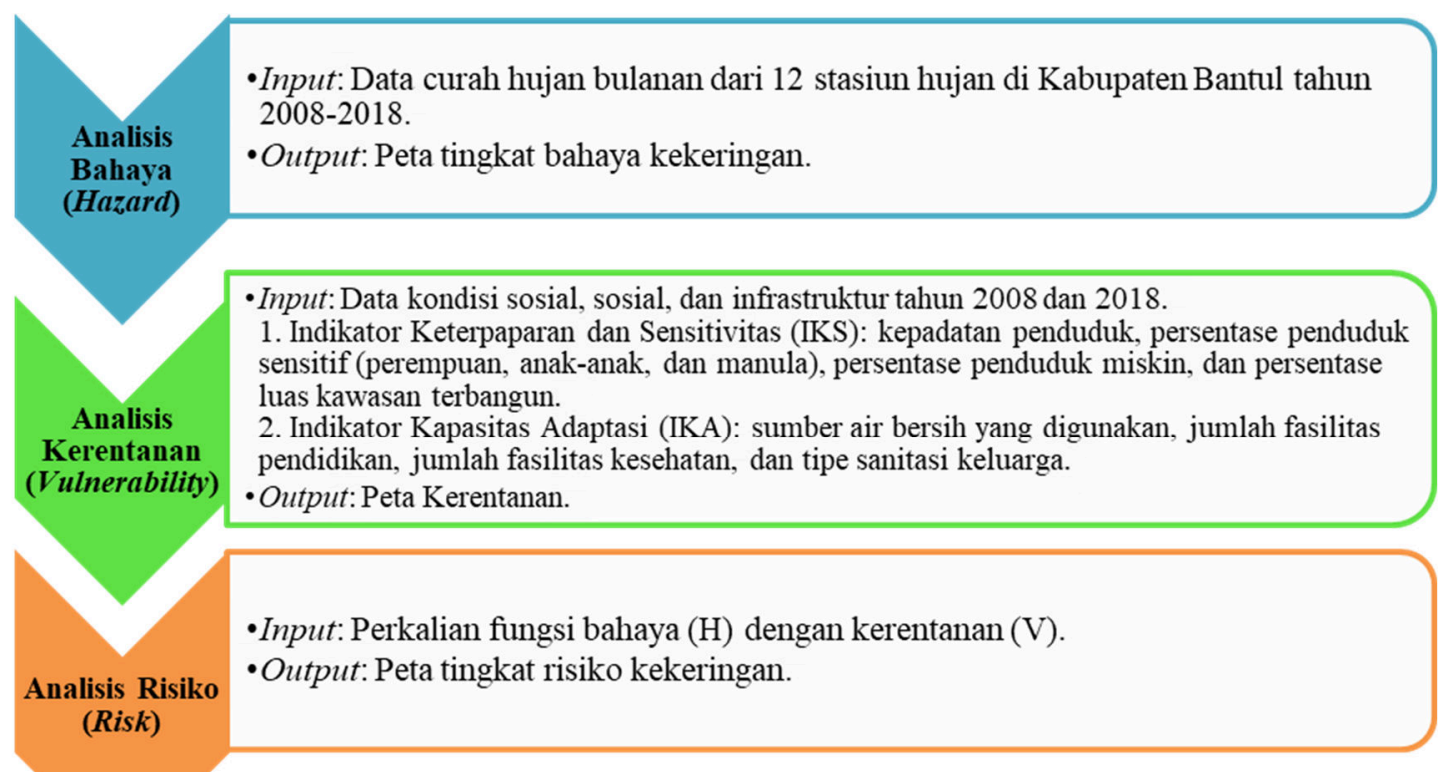

Gambar 1. Framework Penelitian

\subsection{Lokasi Studi}

Studi berlokasi di Kabupaten Bantul dengan unit analisis pada 75 desa di Kabupaten Bantul. Secara geografis Kabupaten Bantul terletak pada $110^{\circ} 12^{\prime} 34^{\prime \prime}$ hingga $110^{\circ} 31^{\prime}$ 08" Bujur Timur dan 7 $7^{\circ} 44^{\prime} 4^{\prime}$ hingga $8^{\circ} 00^{\prime}$ 27" Lintang Selatan. Secara administratif, Kabupaten Bantul terdiri dari 17 kecamatan dan 75 desa dengan luas wilayah \pm 506,85 km2. Gambar 2 menunjukkan peta administrasi Kabupaten Bantul.

Berdasarkan data BPS Kabupaten Bantul (2019), pada tahun 2018 jumlah penduduk total sebanyak 1.006. 692 jiwa. Adapun kecamatan yang memiliki jumlah penduduk tertinggi pada tahun 2018 adalah Kecamatan Banguntapan (145.956 jiwa), Kasihan (129.233 jiwa), dan Sewon (117.200 jiwa). Berdasarkan kenaikan jumlah penduduk selama 10 tahun terakhir antara tahun 2008 hingga 2018, jumlah penduduk di Kecamatan Banguntapan meningkat 38,01\%, Kcamatan Sewon meningkat 30,76\%, dan Kecamatan Kasihan meningkat 28,93\%. Adapun kondisi kepadatan penduduk terlihat pada peta di Gambar 3. 


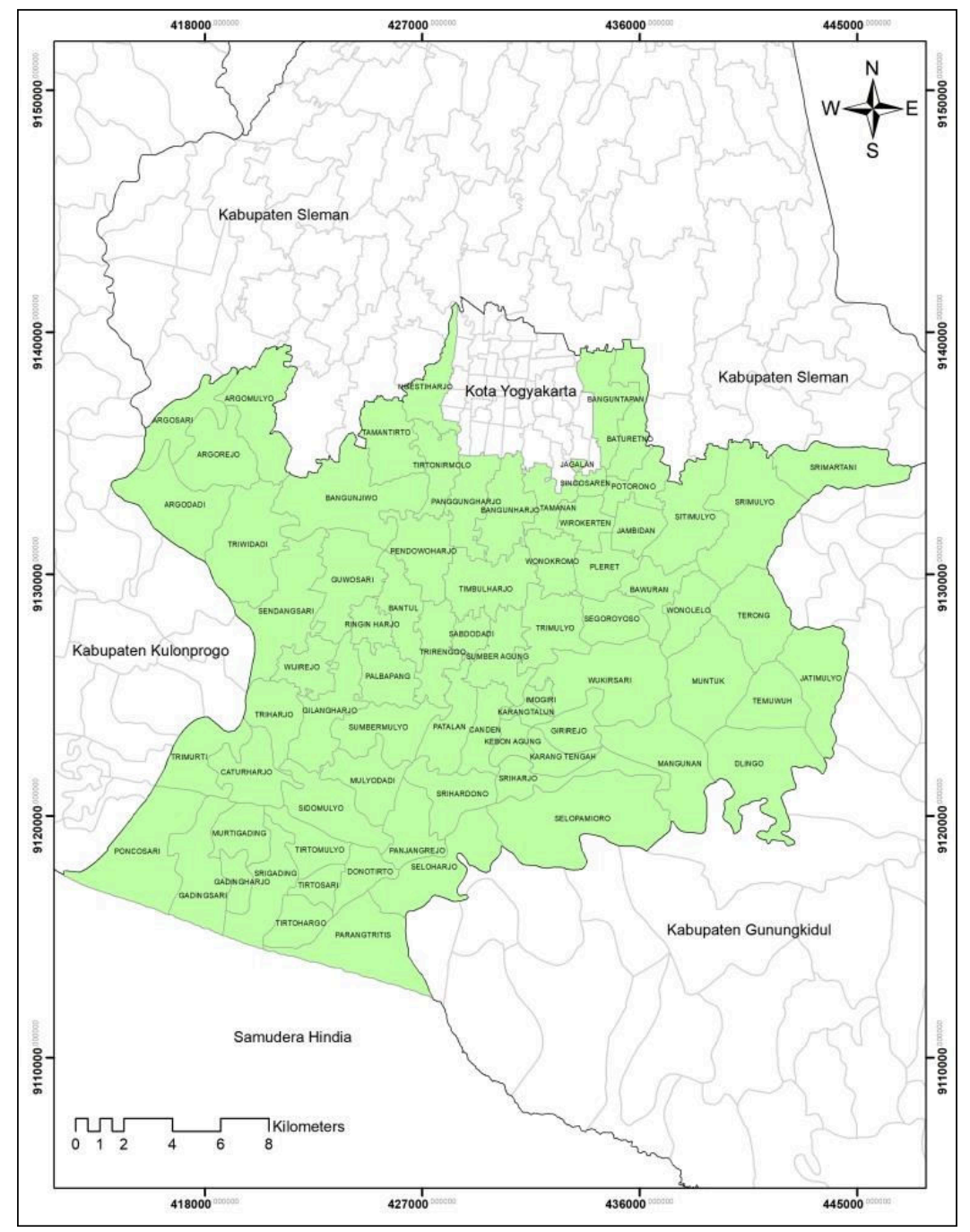

Gambar 2. Peta Administrasi Wilayah Kabupaten Bantul

Jika dilihat berdasarkan kepadatannya, kecamatan dengan karakteristik kota cenderung memiliki kepadatan penduduk tinggi, seperti di Kecamatan Banguntapan, Sewon, Kasihan, dan Bantul yang berbatasan dengan Kota Yogyakarta. Selama tahun 2008 hingga 2018, Kecamatan Banguntapan mengalami kenaikan kepadatan penduduk 38,58\%, Kecamatan Sewon meningkat 31,26\%, dan Kecamatan Kasihan meningkat 30,52\%. Hal ini dapat menunjukkan bahwa infiltrasi karakteristik Kota Yogyakarta bagi kawasan di sekitarnya dapat dilihat dari kondisi jumlah penduduknya. 


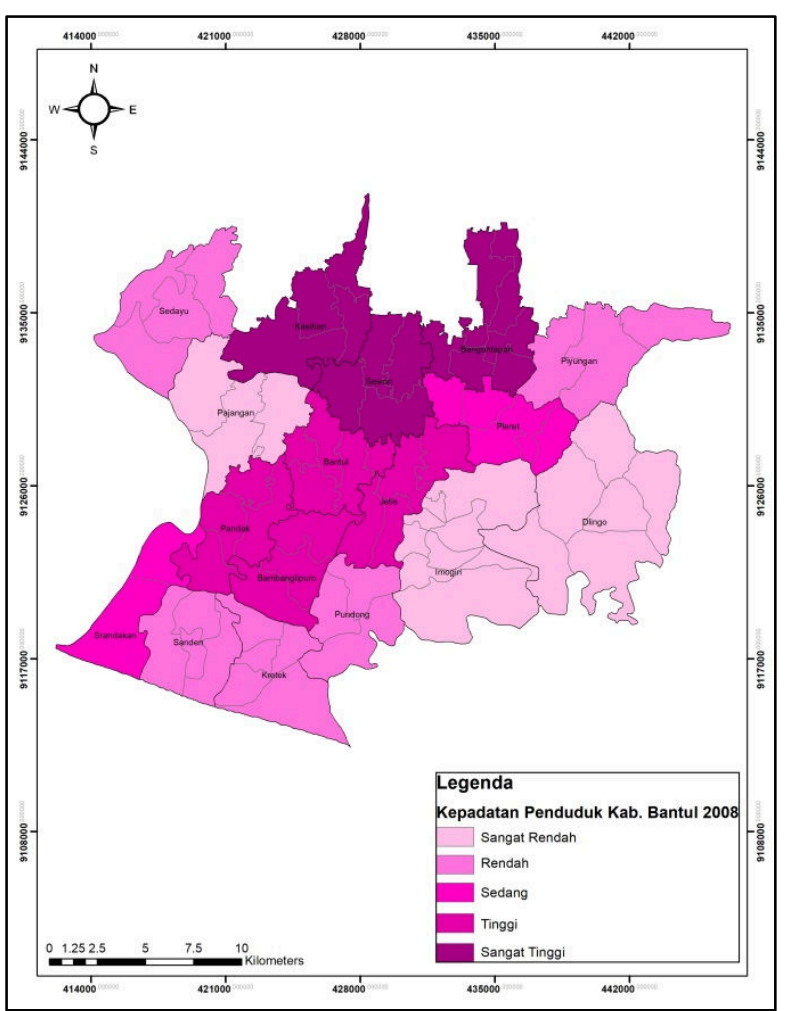

(a)

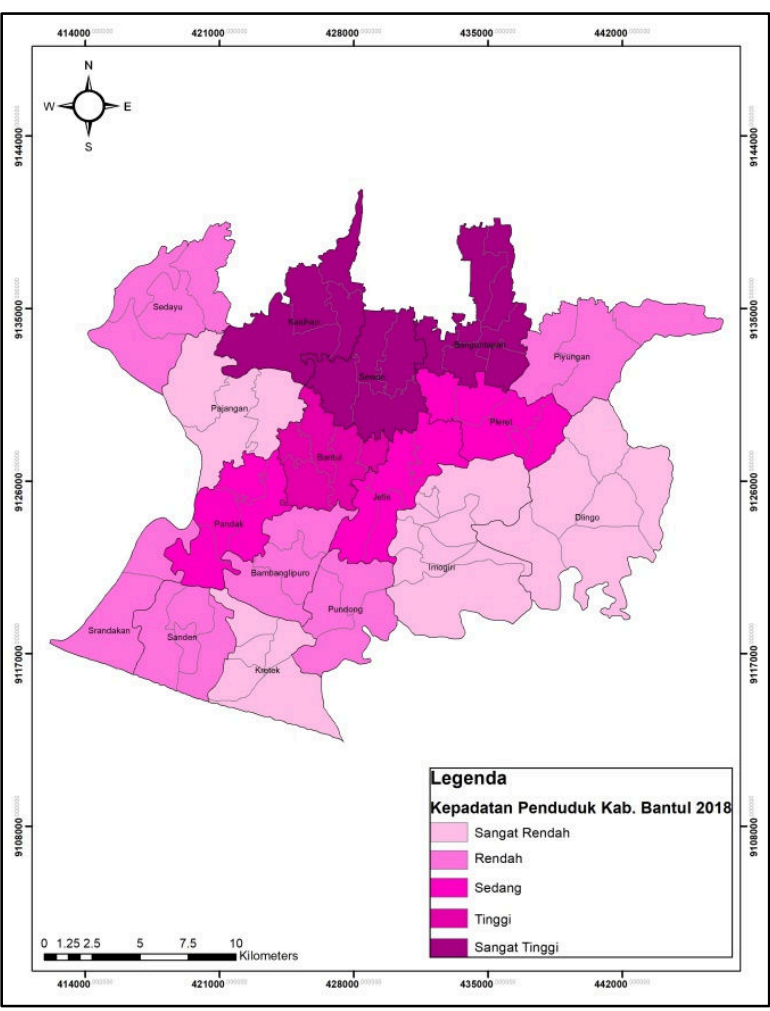

(b)

Gambar 3. Kepadatan Penduduk di Kabupaten Bantul (a) Tahun 2008 dan (b) Tahun 2018

\subsection{Metode Analisis Bahaya Kekeringan}

Penilaian tingkat bencana kekeringan dilakukan dengan menggunakan indeks bencana kekeringan (drought hazard index). Untuk menilai kekeringan perlu didasarkan pada karakteristik kekeringan (He et al., 2011; Kim et al., 2015; Nam et al., 2015; Nasrollahi et al., 2018). Salah satu metode yang dianggap representatif untuk digunakan adalah Standardized Precipitation Index (SPI) yang diperkenalkan oleh McKee et al. pada tahun 1993.

Penelitian ini menggunakan metode SPI untuk menilai tingkat bahaya kekeringan di Kabupaten Bantul sebagaimana digunakan oleh beberapa penelitian, seperti Kim et al., (2015) untuk kasusnya di Korea Selatan, Nasrollahi et al. (2018) di Iran, Shahid \& Behrawan (2008) di Bangladesh, dan Dabanli (2018) di Turki. SPI adalah metode perhitungan indeks bahaya kekeringan yang paling banyak digunakan karena merepresentasikan probabilitas curah hujan pada skala waktu yang berbeda. Metode SPI ini dianggap lebih efektif, efisien, dan praktis karena hanya menggunakan variabel curah hujan. SPI dapat digunakan untuk mendefinisikan 
dan memonitor kekeringan pada skala waktu yang berbeda, seperti 1, 3, 6, 9, 12, 24, dan 48 bulan (McKee et al., 1993).

Dalam penelitian ini, data curah hujan dianalisis dengan menggunakan metode SPI untuk skala waktu bulanan pada tahun 2008 dan 2018. Data curah hujan dikumpulkan dari 12 stasiun hujan di Kabupaten Bantul, yaitu a) Sta. Ringinharjo, b) Sta. Nyemengan, c) Sta. Gandok, d) Sta. Kotagede, e) Sta. Pundong, f) Sta. Barongan, g) Sta. Ngetak, h) Sta. Kebonongan, i) Sta. Piyungan, j) Sta. Sedayu, k) Sta. Ngestiharjo, dan 1) Sta. Dlingo. Sebaran lokasi stasiun hujan ditunjukkan pada Gambar 4. Berdasarkan data curah hujan harian pada tahun 2008 dan 2018 yang digunakan oleh 12 stasiun hujan tersebut, data curah hujan dikelompokkan menjadi data curah hujan bulanan di masing-masing stasiun sebagaimana ditampilkan pada Tabel 1 .

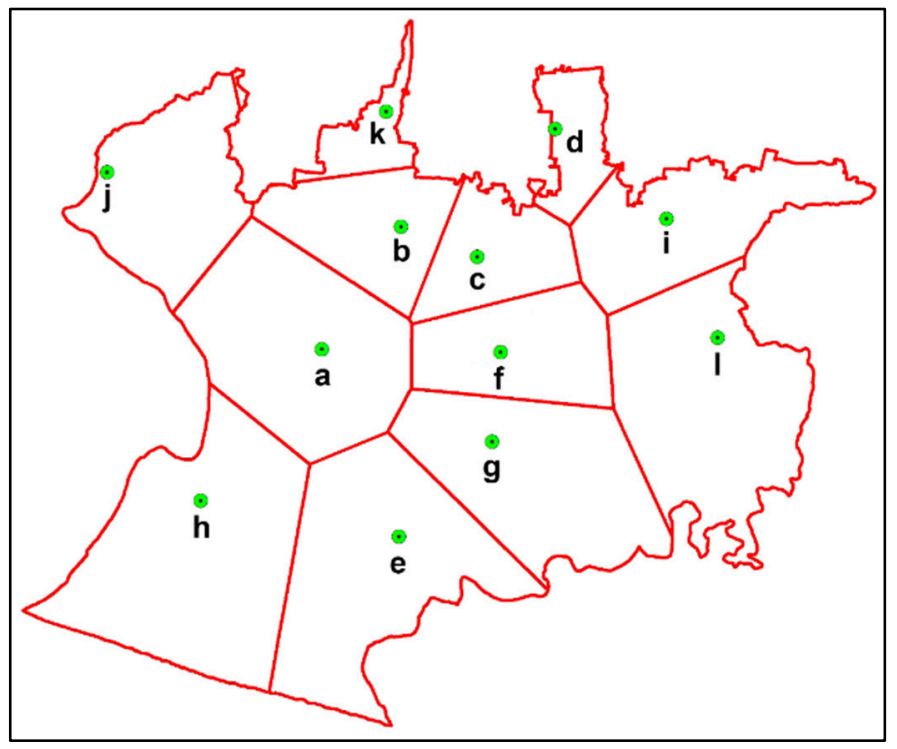

Gambar 4. Sebaran Lokasi 12 Stasiun Hujan di Kabupaten Bantul

Tabel 1. Data Curah Hujan Bulanan Antara Bulan November - April Tahun 2008 dan 2018

\begin{tabular}{|l|c|c|c|c|c|c|c|c|c|c|c|c|}
\hline \multirow{2}{*}{$\begin{array}{c}\text { Stasiun } \\
\text { Hujan }\end{array}$} & \multicolumn{6}{|c|}{ Curah Hujan Bulanan di Musim Penghujan Tahun 2008 dan 2018 } \\
\cline { 2 - 17 } & November & \multicolumn{2}{|c|}{ Desember } & \multicolumn{2}{c|}{ Januari } & \multicolumn{2}{c|}{ Februari } & \multicolumn{2}{c|}{ Maret } & \multicolumn{2}{c|}{ April } \\
\cline { 2 - 16 } & 2008 & 2018 & 2008 & 2018 & 2008 & 2018 & 2008 & 2018 & 2008 & 2018 & 2008 & 2018 \\
\hline Ringinharjo & 478 & 167 & 0 & 13 & 917 & 465 & 465 & 348 & 631 & 324 & 139 & 178 \\
\hline Nyemengan & 356 & 693 & 0 & 693 & 462 & 500 & 164 & 354 & 337 & 317 & 121 & 82 \\
\hline Gandok & 585 & 821 & 0 & 272 & 1248 & 532 & 950 & 286 & 295 & 216 & 233 & 111 \\
\hline Kotagede & 202 & 720 & 126 & 281 & 289 & 538 & 283 & 307 & 220 & 351 & 87 & 109 \\
\hline Pundong & 327 & 917 & 0 & 413 & 694 & 507 & 304 & 322 & 218 & 370 & 145 & 39 \\
\hline Barongan & 150 & 790 & 0 & 314 & 233 & 476 & 187 & 339 & 120 & 269 & 68 & 39 \\
\hline Ngetal & 130 & 659 & 0 & 131 & 303 & 456 & 120 & 253 & 224 & 315 & 78 & 65 \\
\hline Kebonongan & 275 & 235 & 0 & 1287 & 514 & 793 & 325 & 499 & 384 & 644 & 126 & 47 \\
\hline
\end{tabular}




\begin{tabular}{|l|l|l|c|c|c|c|c|c|c|c|c|c|}
\hline \multirow{2}{*}{$\begin{array}{c}\text { Stasiun } \\
\text { Hujan }\end{array}$} & \multicolumn{8}{|c|}{ Curah Hujan Bulanan di Musim Penghujan Tahun 2008 dan 2018 } \\
\cline { 2 - 15 } & November & Desember & \multicolumn{2}{c|}{ Januari } & Februari & \multicolumn{2}{c|}{ Maret } & \multicolumn{2}{c|}{ April } \\
\cline { 2 - 14 } & 2008 & 2018 & 2008 & 2018 & 2008 & 2018 & 2008 & 2018 & 2008 & 2018 & 2008 & 2018 \\
\hline Piyungan & 228 & 446 & 0 & 117 & 995 & 587 & 516 & 282 & 471 & 454 & 387 & 105 \\
\hline Sedayu & 596 & 495 & 0 & 495 & 521 & 491 & 302 & 347 & 318 & 215 & 173 & 84 \\
\hline Ngestiharjo & 459 & 559 & 0 & 559 & 629 & 527 & 382 & 329 & 419 & 235 & 156 & 97 \\
\hline Dlingo & 680 & 532 & 0 & 242 & 995 & 562 & 390 & 362 & 570 & 477 & 250 & 229 \\
\hline
\end{tabular}

Sumber: BMKG Bantul, 2008-2018

Tabel 1 (Lanjutan). Data Curah Hujan Bulanan Antara Bulan Mei - Oktober Tahun 2008 dan 2018

\begin{tabular}{|c|c|c|c|c|c|c|c|c|c|c|c|c|}
\hline \multirow{3}{*}{$\begin{array}{l}\text { Stasiun } \\
\text { Hujan }\end{array}$} & \multicolumn{12}{|c|}{ Curah Hujan Bulanan di Musim Kemarau Tahun 2008 dan 2018} \\
\hline & \multicolumn{2}{|c|}{ Mei } & \multicolumn{2}{|c|}{ Juni } & \multicolumn{2}{|c|}{ Juli } & \multicolumn{2}{|c|}{ Agustus } & \multicolumn{2}{|c|}{ September } & \multicolumn{2}{|c|}{ Oktober } \\
\hline & 2008 & 2018 & 2008 & 2018 & 2008 & 2018 & 2008 & 2018 & 2008 & 2018 & 2008 & 2018 \\
\hline Ringinharjo & 28 & 0 & 11 & 0 & 0 & 0 & 0 & 0 & 0 & 4 & 315 & 0 \\
\hline Nyemengan & 39 & 0 & 13 & 0 & 0 & 0 & 0 & 0 & 0 & 0 & 170 & 99 \\
\hline Gandok & 70 & 103 & 0 & 5 & 0 & 0 & 0 & 0 & 0 & 17 & 232 & 67 \\
\hline Kotagede & 22 & 41 & 0 & 1 & 0 & 0 & 0 & 0 & 0 & 24 & 96 & 37 \\
\hline Pundong & 0 & 24 & 0 & 0 & 0 & 0 & 0 & 0 & 0 & 0 & 205 & 40 \\
\hline Barongan & 0 & 23 & 0 & 0 & 0 & 0 & 0 & 0 & 0 & 3 & 106 & 47 \\
\hline Ngetal & 0 & 42 & 0 & 5 & 0 & 2 & 0 & 0 & 0 & 0 & 81 & 0 \\
\hline Kebonongan & 0 & 0 & 0 & 0 & 0 & 0 & 0 & 0 & 0 & 5 & 223 & 64 \\
\hline Piyungan & 62 & 29 & 0 & 1 & 0 & 2 & 0 & 0 & 0 & 7 & 166 & 0 \\
\hline Sedayu & 0 & 0 & 0 & 0 & 0 & 0 & 0 & 0 & 0 & 84 & 57 & 61 \\
\hline Ngestiharjo & 22 & 22 & 29 & 16 & 0 & 0 & 0 & 0 & 0 & 1 & 163 & 156 \\
\hline Dlingo & 0 & 70 & 0 & 87 & 0 & 0 & 0 & 0 & 0 & 7 & 143 & 14 \\
\hline
\end{tabular}

Sumber: BMKG Bantul, 2008-2018

Tahapan analisis perhitungan curah hujan dimulai dari perhitungan hujan bulanan dan simpangan bakunya dari masing-masing stasiun hujan pada tahun 2008 dan 2018. Selanjutnya dilakukan perhitungan nilai SPI berdasarkan data hujan bulanan untuk menentukan indeks kekeringan di masing-masing stasiun hujan pada tahun 2008 dan 2018. Metode indeks kekeringan SPI adalah indeks yang digunakan untuk menentukan penyimpangan curah hujan terhadap normalnya dalam satu periode yang panjang. Nilai SPI dihitung menggunakan metode Statistik Probabilistik Distribusi Gamma. Apabila hujan yang turun mengecil, maka kandungan air dalam tanah dan debit aliran berkurang sehingga dapat menimbulkan defisit air atau kekeringan. Cara mengklasifikasikan indeks kekeringan SPI dapat dilihat pada persamaan (1). Tahap perhitungan dilanjutkan dengan menggunakan persamaan (2). 


$$
Z_{i j}=\frac{X_{i j}-\bar{X}_{j}}{\sigma_{j}}
$$

Keterangan:

$\mathrm{Zij}=$ peubah $\mathrm{Z}$, tahun ke i bulan ke $\mathrm{j}$,

$\mathrm{Xij}=$ hujan bulanan tahun ke i bulan ke $\mathrm{j}$,

$\mathrm{Xj} \quad=$ hujan bulan $\mathrm{j}$, rata-rata,

$\sigma \mathrm{j} \quad=$ simpangan baku bulanan.

Dengan simpangan baku:

$$
\sigma=\sqrt{\frac{(x-\bar{x})^{2}}{n-1}}
$$

Keterangan:

$$
\begin{array}{ll}
x & =\text { data curah hujan } \\
\bar{x} & =\text { jumlah rata-rata curah hujan } \\
\mathrm{n} & =\text { jumlah data }
\end{array}
$$

Indeks kekeringan diklasifikasikan berdasarkan Standarized Precipitation Index (SPI) yang merupakan kriteria tingkat kekeringan meteorologis (Tabel 2).

Tabel 2. Kriteria Ketajaman Kekeringan Kekeringan Berdasarkan Nilai SPI

\begin{tabular}{|c|c|}
\hline Nilai & Klasifikasi \\
\hline$>2,00$ & Amat Sangat Basah \\
\hline $1,50-1,99$ & Sangat Basah \\
\hline $1,00-1,49$ & Basah \\
\hline$(-0,99)-(0,99)$ & Normal \\
\hline$(-1,00)-(-1,49)$ & Kering \\
\hline$(-1,50)-(-1,99)$ & Sangat Kering \\
\hline$<(-2,00)$ & Amat Sangat Kering \\
\hline
\end{tabular}

Sumber: McKee et al., 1993

Selanjutnya dilakukan analisis Inverse Distance Weighted (IDW) untuk membuat peta persebaran daerah kerawanan bencana kekeringan di Kabupaten Bantul berdasarkan nilai indeks kekeringan SPI pada tahun 2008 dan 2018 dengan bantuan software ArcGIS. Metode IDW merupakan salah satu metode interpolasi yang digunakan dalam ArcGIS untuk 
mendapatkan data berdasarkan data-data di sekitarnya yang telah diketahui. Selanjutnya hasil analisis perhitungan SPI dikombinasikan dengan probabilitas kejadian untuk menghitung Drought Hazard Index (DHI) guna mengetahui tingkat bahaya kekeringan pada suatu lokasi. Selanjutnya hasil nilai DHI dinormalisasi dengan rentang $0-1$ dan diklasifikasikan menjadi lima kelas seperti ditampilkan di Tabel 3.

Tabel 3. Klasifikasi Tingkat Bahaya Kekeringan di Kabupaten Bantul

\begin{tabular}{|l|c|c|}
\hline \multicolumn{1}{|c|}{ Elemen Bahaya } & Klasifikasi & Indeks Bahaya \\
\hline \multirow{4}{*}{$\begin{array}{l}\text { Peta Bahaya } \\
\text { (Drought Hazard }\end{array}$} & Sangat Bahaya & $>0,91$ \\
\cline { 2 - 3 } Index) & Bahaya & $0,66-0,90$ \\
\cline { 2 - 3 } & Agak Bahaya & $0,33-0,65$ \\
\cline { 2 - 3 } & Kurang Bahaya & $0,11-0,32$ \\
\cline { 2 - 3 } & Tidak Bahaya & $<0,10$ \\
\hline
\end{tabular}

\subsection{Metode Analisis Kerentanan}

Analisis tingkat kerentanan dilakukan dengan teknik analisis skoring. Analisis kerentanan dilakukan dengan menggunakan tiga komponen, yaitu keterpaparan (exposure), sensitivitas (sensitivity), dan kapasitas adaptasi (adaptive capacity) yang didasarkan pada indikator sosial ekonomi serta infrastruktur. Indikator yang digunakan untuk menilai keterpaparan dan sensitivitas (IKS) meliputi kepadatan penduduk, persentase penduduk sensitif (perempuan, anak-anak, dan manula), persentase penduduk miskin, dan persentase luas kawasan terbangun. Penduduk sensitif dan miskin cenderung lebih mengalami kerentanan yang tinggi terkait dengan kebertahanannya saat terjadi bencana (Rasch, 2015). Dari segi penggunaan lahan, lahan dengan proporsi terbangun yang lebih besar cenderung lebih rentan terhadap bencana. Ini menyangkut dampak kerugian yang dapat ditimbulkan (Li et al., 2016). Wilayah dengan kepadatan penduduk tinggi juga cenderung lebih rentan (Rasch, 2015).

Indikator kapasitas adaptasi (IKA) meliputi sumber air bersih yang digunakan (PDAM/ air tanah/ lainnya), jumlah fasilitas pendidikan, jumlah fasilitas kesehatan, dan tipe sanitasi keluarga (menggunakan jamban atau tidak). Ketersediaan sarana air bersih dan sanitasi menentukan kemungkinan kejadian penyakit di suatu rumah tangga (Rasch, 2015). Rumah dengan sarana air bersih dan sanitasi yang memadai dianggap lebih adaptif terhadap bencana.

Penilaian tingkat kerentanan dilakukan dengan menggunakan data sekunder bersumber dari data Potensi Desa serta data dari buku kecamatan dalam angka se-Kabupaten Bantul 
tahun 2008 dan 2018 yang diterbitkan oleh BPS. Langkah untuk menganalisis kerentanan sebagaimana dijelaskan oleh CCROM (dalam Mercy Corps Indonesia, 2017) meliputi:

1. Menentukan indikator dan data didasarkan hasil telaah literatur dan ketersediaan data sekunder.

2. Membobotkan setiap indikator IKS dan IKA dengan nilai maksimal masing-masing 1. Bobot ditentukan dari hasil telaah literatur dan analisis peneliti.

3. Melakukan perhitungan data dengan skoring untuk masing-masing variabel.

4. Melakukan normalisasi data dengan rentang nilai maksimal 1 dan nilai terendah 0 . Normalisasi bertujuan agar masing-masing data dapat dikomparasikan hasilnya. Normalisasi dilakukan dengan rumus:

Nilai normalisasi $=\underline{\text { Hasil perhitungan atau nilai skoring }}$

Nilai perhitungan/ skor maksimal

5. Melakukan pembobotan dengan cara mengkalikan hasil normalisasi dengan bobot masing-masing variabel.

6. Menghitung total nilai indikator IKS dan IKA.

7. Melakukan perhitungan anomali IKS dan IKA (ANO IKS dan IKA) dengan cara mengurangi nilai dengan 0,5 . Nilai 0,5 didapatkan dari masing-masing nilai maksimal untuk IKS dan IKA yang bernilai 1. Dengan mengurangi dengan 0,5 maka nilai IKS dan IKA akan berada pada rentang $-0,5$ hingga $+0,5$.

8. Menghitung indeks kerentanan (IKR) dengan kategorisasi nilai kerentanan sebagaimana terjabarkan di Tabel 4. IKR digolongkan menjadi lima kelas.

Tabel 4. Kategorisasi Tingkat Kerentanan Berdasarkan Nilai IKS dan IKA

\begin{tabular}{|l|l|}
\hline \multicolumn{1}{|c|}{ Hasil Perhitungan } & \multicolumn{1}{c|}{ Kategori } \\
\hline Ano.IKS $<0$, Ano.IKA $>0$, Ano IKS-IKA $<-0,25$ & Tidak Rentan \\
\hline Ano.IKS $>0$, Ano.IKA $>0$, Ano IKS+IKA $>0,25$ & Kurang Rentan \\
\hline $\begin{array}{l}\text { Ano IKS }+ \text { IKA }<0,25, \text { Ano.IKS }+ \text { IKA }>-0,25, \text { Ano } \\
\text { IKS-IKA }<0,25, \text { Ano.IKS-IKA }>-0,25\end{array}$ & Agak Rentan \\
\hline Ano.IKS $<0$, Ano.IKA $<0$, Ano IKS+IKA $<-0,25$ & Rentan \\
\hline Ano.IKS $>0$, Ano.IKA $<0$, Ano IKS-IKA $>0,25$ & Sangat Rentan \\
\hline
\end{tabular}

Sumber: CCROM, 2013 dalam Mercy Corps Indonesia, 2017

\subsection{Metode Analisis Risiko}

Analisis risiko dilakukan dengan mengkalikan bahaya $(\mathrm{H})$ dengan kerentanan $(\mathrm{V})$ yang hasilnya ditentukan ke dalam tujuh kelas sebagaimana ditunjukkan di Tabel 5. Output analisis 
risiko ditampilkan dalam bentuk pemetaan risiko bencana yang merupakan hasil overlay dari peta bahaya dan kerentanan.

Tabel 5. Kategorisasi Tingkat Risiko Berdasarkan Analisis Bahaya (H) dan Analisis Kerentanan (V)

\begin{tabular}{|c|c|c|c|c|c|c|}
\hline & \multicolumn{5}{|c|}{ Bahaya (H) } \\
\hline & & $\begin{array}{l}\text { Sangat } \\
\text { Bahaya }\end{array}$ & Bahaya & $\begin{array}{c}\text { Agak } \\
\text { Bahaya }\end{array}$ & $\begin{array}{l}\text { Kurang } \\
\text { Bahaya }\end{array}$ & $\begin{array}{c}\text { Tidak } \\
\text { Bahaya }\end{array}$ \\
\hline \multirow{5}{*}{ 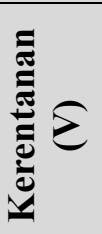 } & Sangat Rentan & SST & SST & ST & $\mathrm{T}$ & $\mathrm{S}$ \\
\hline & Rentan & SST & ST & $\mathrm{T}$ & $\mathrm{S}$ & $\mathrm{R}$ \\
\hline & Agak Rentan & ST & $\mathrm{T}$ & $\mathrm{S}$ & $\mathrm{R}$ & SR \\
\hline & Kurang Rentan & $\mathrm{T}$ & $\mathrm{S}$ & $\mathrm{R}$ & SR & SSR \\
\hline & Tidak Rentan & $\mathrm{S}$ & $\mathrm{R}$ & SR & SSR & SSR \\
\hline
\end{tabular}

Sumber: CCROM, 2013 dalam Mercy Corps Indonesia, 2017

\section{HASIL DAN PEMBAHASAN}

\subsection{Analisis Bahaya Kekeringan}

Analisis bahaya kekeringan dilakukan dengan menggunakan metode SPI berdasarkan data curah hujan tahun 2008-2018. Gambar 5 menunjukkan hasil pemetaan analisis kekeringan di Kabupaten Bantul. Hasil perhitungan DHI menunjukkan bahwa sebanyak 31 desa (41,33\%) di Kabupaten Bantul tergolong bahaya terhadap bencana kekeringan. Sementara itu, 28 desa (37,33\%) tergolong agak bahaya, 11 desa (14,67\%) kurang bahaya, 3 desa (4\%) termasuk tidak bahaya, dan hanya 2 desa (2,67\%) yang tergolong sangat bahaya. Kondisi menunjukkan bahwa level bahaya kekeringan di Kabupaten Bantul tergolong sedang namun cenderung tinggi pada wilayah Bantul bagian selatan dan tengah.

Jika dilihat berdasarkan karakteristik wilayahnya, wilayah Bantul bagian utara cenderung memiliki level kurang bahaya atau tidak bahaya. Wilayah Bantul bagian utara adalah wilayah yang memiliki karakteristik perkotaan yang nampak karena berbatasan langsung dengan Kota Yogyakarta sehingga mendapatkan dampak infiltrasi langsung dari perkembangan Kota Yogyakarta. Sementara itu, wilayah di Bantul bagian selatan yang sebagian besar masih berkarakteristik perdesaan, cenderung mengalami bahaya kekeringan tingkat tinggi. Hal ini dikarenakan masih didominasinya wilayah dengan penggunaan lahan non terbangun, seperti area persawahan yang masih bergantung pada aspek meteorologis, seperti jumlah curah hujan. 
Kejadian kekeringan di Kabupaten Bantul kurang berjalan selaras dengan karakteristik wilayah. Hal ini dikarenakan kekeringan di kawasan perkotaan (urban drought) bersifat lebih kompleks karena menyangkut aspek fisik dan antropogenik, seperti kondisi iklim, hidrologi, aktivitas manusia dan faktor lingkungan yang mempengaruhi keseimbangan ketersediaan dan kebutuhan air (Zhang et al., 2019). Kekeringan di perkotaan juga sering dikonotasikan dengan kelangkaan air, dimana keseimbangan kebutuhan dan ketersediaan air lebih mempengaruhi kondisi, dibandingkan di kawasan perdesaan yang kekeringannya lebih banyak disebabkan oleh kondisi meteorologis.

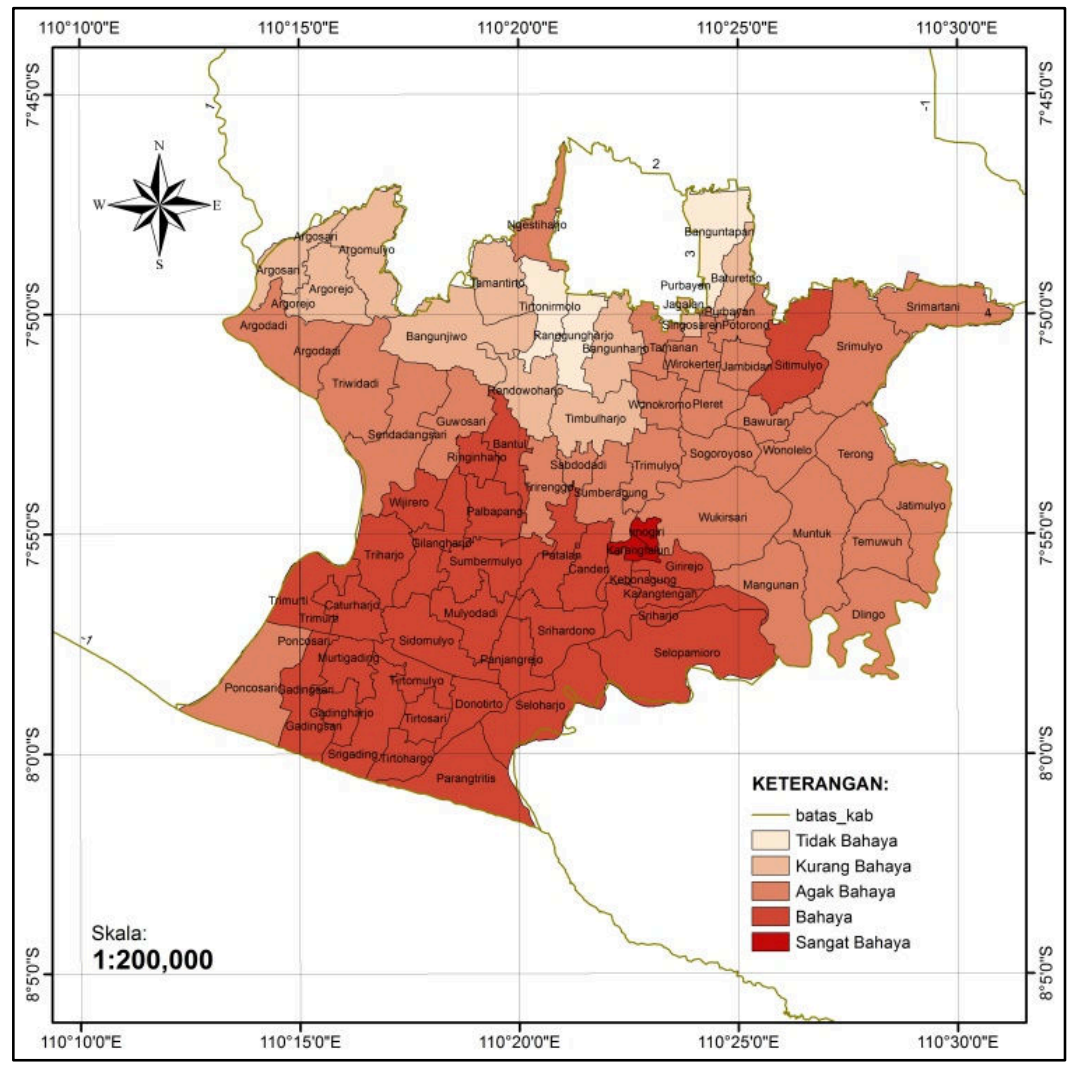

Gambar 5. Tingkat Bahaya Kekeringan di Kabupaten Bantul Tahun 2008-2018

Selain itu, menurut Triadmodjo (2008) sebaran lokasi stasiun hujan juga dapat mempengaruhi kejadian kekeringan. Ini dikarenakan terkait data curah hujan yang dikolektif oleh masing-masing stasiun hujan. Semakin jarang atau berjauhan jarak lokasi stasiun hujannya, maka bias data curah hujan juga akan semakin besar terkait dengan covering area dari stasiun hujan tersebut. 


\subsection{Analisis Kerentanan}

Analisis kerentanan dilakukan dengan indikator sosial ekonomi dan infrastruktur. Perbandingan hasil analisis kerentanan di Kabupaten Bantul tahun 2008 dan 2018 ditampilkan pada peta di Gambar 6. Hasil pemetaan menunjukkan bahwa Kabupaten Bantul memiliki kerentanan yang tinggi. Ini dapat dilihat dari persentase wilayah yang mengalami kerentanan cenderung meningkat. Pada tahun 2008, sebanyak 52\% desa tergolong rentan dan $48 \%$ desa sangat rentan. Kondisi ini meningkat menjadi $68 \%$ desa tergolong sangat rentan dan $32 \%$ desa tergolong rentan pada tahun 2018 .

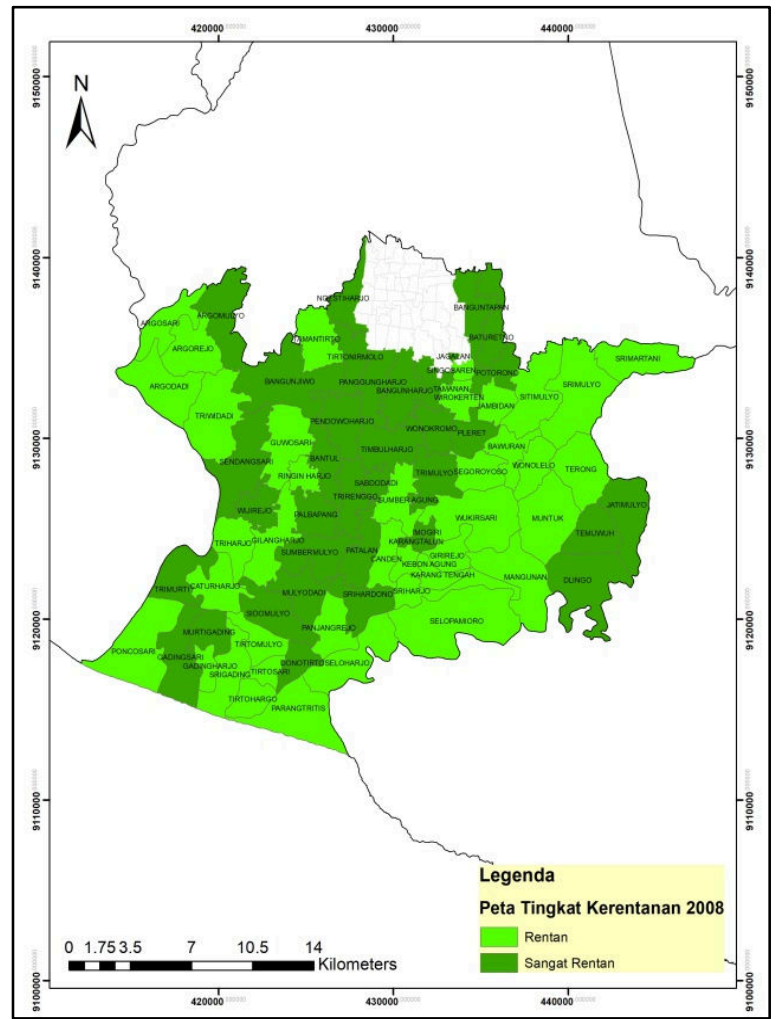

(a)

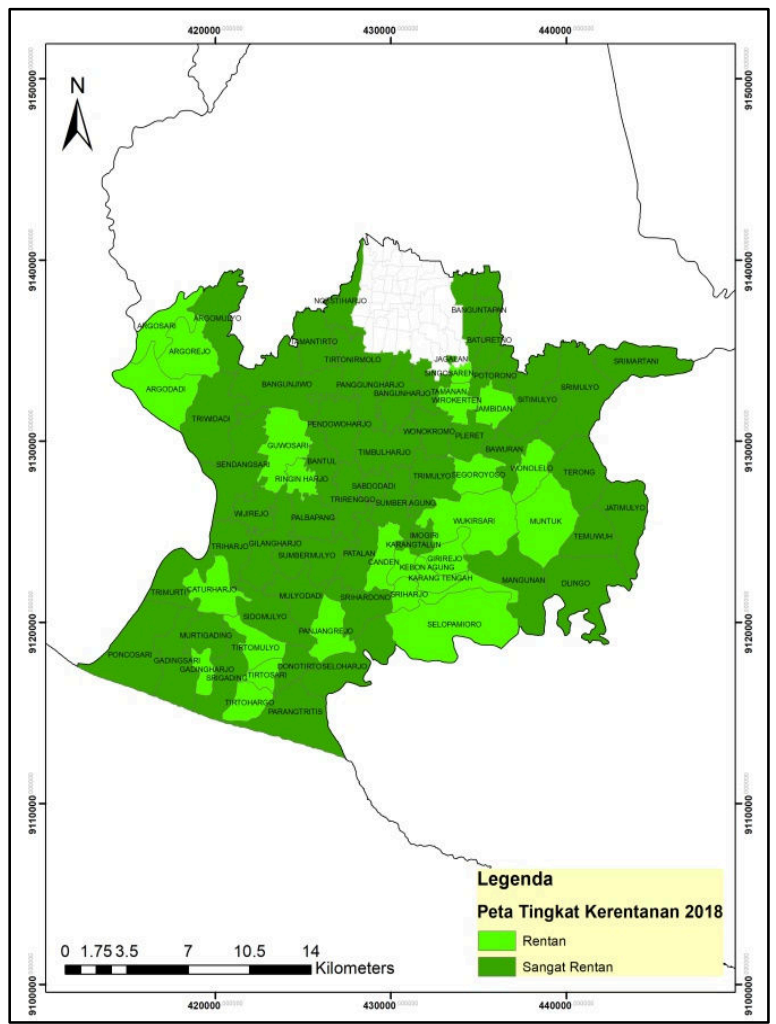

(b)

Gambar 6. Tingkat Kerentanan di Kabupaten Bantul (a) Tahun 2008 dan (b) Tahun 2018

Secara spasial, kondisi kerentanan di Kabupaten Bantul rentan terjadi di wilayah tengah dan utara yang notabene merupakan kawasan perkotaan dari Kabupaten Bantul. Namun demikian, pada tahun 2018 sebaran spasial kerentanan semakin meluas ke wilayah selatan dan timur yang dominasinya masih terkategori sebagai kawasan perdesaan. Beberapa hal yang mempengaruhi peningkatan kerentanan antara tahun 2008 dan 2018 ini karena semakin 
masifnya perubahan penggunaan lahan menjadi lahan terbangun, kepadatan populasi, dan ketersediaan infrastruktur.

Li et al. (2016) mengungkapkan bahwa kerentanan berpeluang meningkat apabila proporsi penggunaan lahan terbangun juga meningkat. Hasil analisis kerentanan menunjukkan bahwa terdapat peningkatan proporsi penggunaan lahan terbangun di beberapa kecamatan, seperti di Kecamatan Srandakan, Kretek, dan Pundong yang terletak di selatan wilayah kabupaten. Perkembangan aktivitas pariwisata, terutama wisata pantai mendorong perkembangan fungsi kawasan. Sementara itu, untuk kecamatan yang berada di wilayah utara, seperti Kecamatan Banguntapan, Kasihan, Sewon, dan Bantul rata-rata memiliki proporsi penggunaan lahan terbangun di atas 50\% karena perkembangan fungsi kawasan menjadi kawasan permukiman.

Rasch (2015) menyatakan bahwa kepadatan populasi juga turut mempengaruhi tingginya kerentanan, dimana semakin padat suatu area akan semakin rentan. Hal ini sejalan dengan kondisi di Kabupaten Bantul, dimana kecamatan dengan kepadatan penduduk sedang hingga tinggi juga cenderung lebih rentan, seperti di Kecamatan Banguntapan, Sewon, Kasihan, Bantul, Pandak, Bambang Lipuro, dan Jetis. Rasch (2015) juga berpendapat bahwa kawasan perkotaan yang sarat akan infrastruktur juga mempengaruhi derajat kerentanan karena berpeluang mengalami banyak kerugian maupun kerusakan.

Tingginya tingkat kerentanan juga dipengaruhi oleh kurangnya kapasitas adaptasi. Indikator kapasitas adaptasi yang digunakan dilihat dari penyediaan infrastruktur, seperti fasilitas pendidikan, kesehatan, air bersih, dan sanitasi. Padahal ketersediaan infrastruktur dapat membantu penduduk untuk mengatasi dampak bencana. Menurut Rasch (2015), ketersediaan sarana air bersih dan sanitasi merefleksikan kondisi kesehatan populasi. Rumah dengan sanitasi pribadi dan air bersih yang terjamin akan memiliki kapasitas adaptasi yang lebih baik. Sementara itu, jumlah fasilitas pendidikan dan kesehatan menunjukkan akses masyarakat untuk menjangkaunya. Kondisi di Kabupaten Bantul menunjukkan bahwa jika dilihat dari ketersediaan dan sebaran fasilitas, khususnya fasilitas kesehatan masih kurang terutama untuk jenis fasilitas puskesmas dan poliklinik sebagai fasilitas pertama yang melayani masyarakat. Di samping itu, sebagian besar wilayah di Kabupaten Bantul masih menggunakan air sumur/ non PDAM untuk memenuhi sumber air bersih. Padahal keberadaan air sumur bergantung pada debit air. 


\subsection{Analisis Risiko Kekeringan}

Analisis risiko dilakukan dengan mengkalikan fungsi bahaya $(\mathrm{H})$ dengan kerentanan (V). Hasil analisis risiko bahaya kekeringan ditampilkan pada peta di Gambar 7. Adapun sebaran wilayah tingkat desa berdasarkan derajat risikonya terhadap bahaya kekeringan ditampilkan pada Tabel 6. Analisis risiko menunjukkan bahwa sekitar $60-70 \%$ desa di Kabupaten Bantul berisiko tinggi mengalami kekeringan. Tingginya tingkat risiko ini dipengaruhi oleh faktor bahaya dan kerentanan yang melatarbelakanginya. Berdasarkan penilaian bahaya dengan menggunakan DHI, kekeringan di Kabupaten Bantul tergolong cukup tinggi. Sementara itu, jika dilihat dari kerentanannya juga tergolong rentan dan sangat rentan. Wilayah berisiko tinggi terdapat di wilayah Bantul bagian tengah, selatan dan timur.

Tabel 6. Perbandingan Persentase Tingkat Risiko Bahaya Kekeringan Tahun 2008 dan 2018 di Kabupaten Bantul

\begin{tabular}{|c|c|c|}
\hline \multirow{2}{*}{ Tingkat Risiko } & \multicolumn{2}{|c|}{ Jumlah Desa (\%) } \\
\cline { 2 - 3 } & $\mathbf{2 0 0 8}$ & $\mathbf{2 0 1 8}$ \\
\hline Sangat Sangat Tinggi & $20,0 \%$ & $28,0 \%$ \\
\hline Sangat Tinggi & $40,0 \%$ & $42,7 \%$ \\
\hline Tinggi & $32,0 \%$ & $22,7 \%$ \\
\hline Sedang & $4,0 \%$ & $2,7 \%$ \\
\hline Rendah & $4,0 \%$ & $4,0 \%$ \\
\hline Sangat Rendah & $0,0 \%$ & $0,0 \%$ \\
\hline Sangat Sangat Rendah & $0,0 \%$ & $0,0 \%$ \\
\hline
\end{tabular}

Tabel 6 menunjukkan bahwa selama kurun waktu 10 tahun terakhir terdapat peningkatan jumlah desa yang tergolong berisiko sangat sangat tinggi dan sangat tinggi kekeringan. Pada tahun 2008 terdapat 15 desa (20\%) yang tergolong sangat sangat tinggi dan meningkat menjadi 21 desa (28\%) pada tahun 2018. Sementara itu, untuk kategori sangat tinggi meningkat dari sejumlah 30 desa (40\%) di tahun 2008 dan bertambah menjadi 32 desa $(42,7 \%)$ pada tahun 2018. Hal ini menunjukkan bahwa terjadi perluasan wilayah berisiko kekeringan di Kabupaten Bantul baik disebabkan oleh meningkatnya peluang terjadinya bahaya kekeringan maupun kondisi kerentanan yang semakin tinggi.

Wilayah yang memiliki risiko tinggi dikarenakan tingginya bahaya kekeringan dan kerentanan yang terjadi di wilayah tersebut. Wilayah berisiko tinggi cenderung terjadi pada wilayah tengah dan selatan yang memiliki kategori bahaya tingkat menengah hingga tinggi 
serta derajat kerentanan rentan dan sangat rentan. Jika dilihat dari karakteristiknya, risiko tinggi juga cenderung ditemukan pada wilayah dengan karakteristik perdesaan. Faktor probabilitas terjadinya bahaya kekeringan lebih mempengaruhi kondisi risiko kekeringan di Kabupaten Bantul.

Pada wilayah dengan karakteristik perkotaan seperti pada desa-desa di Kecamatan Bantul dan Banguntapan, memiliki risiko yang sedang disebabkan kepadatan populasi yang tinggi namun ancaman kekeringan tidak begitu tinggi. Sementara itu, wilayah berisiko sangat tinggi dan sangat sangat tinggi cenderung terjadi di wilayah perdesaan atau pertanian yang masih bergantung pada kondisi curah hujan, seperti pada desa-desa di Kecamatan Kretek, Pundong, dan Bambang Lipuro.

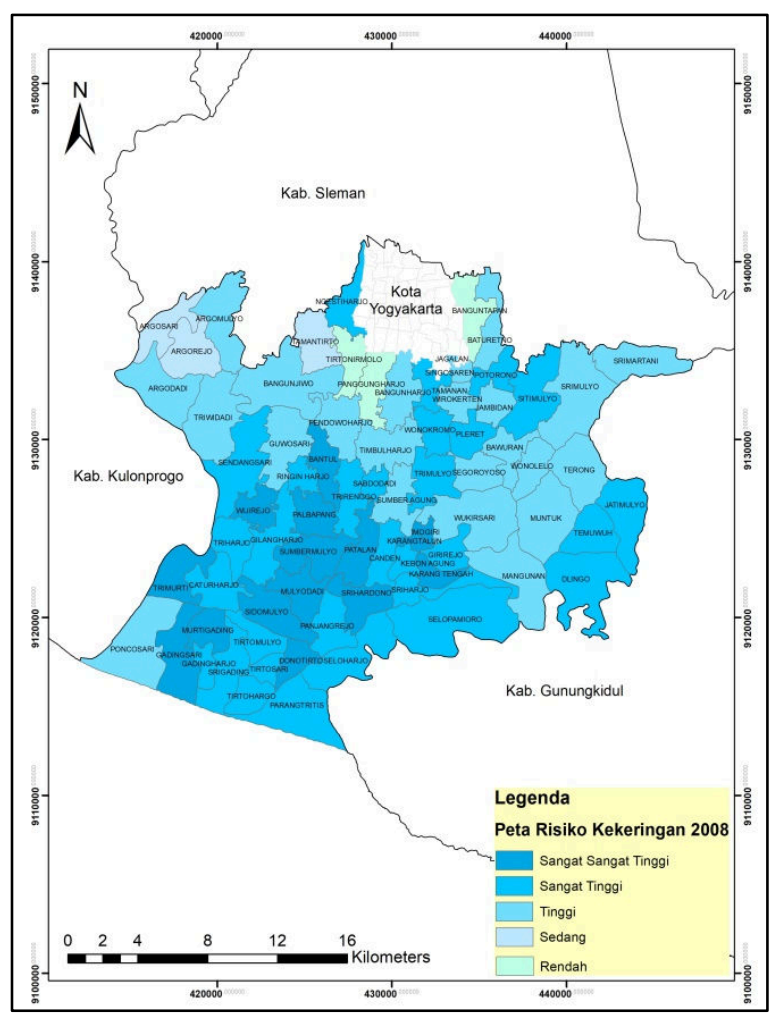

(a)

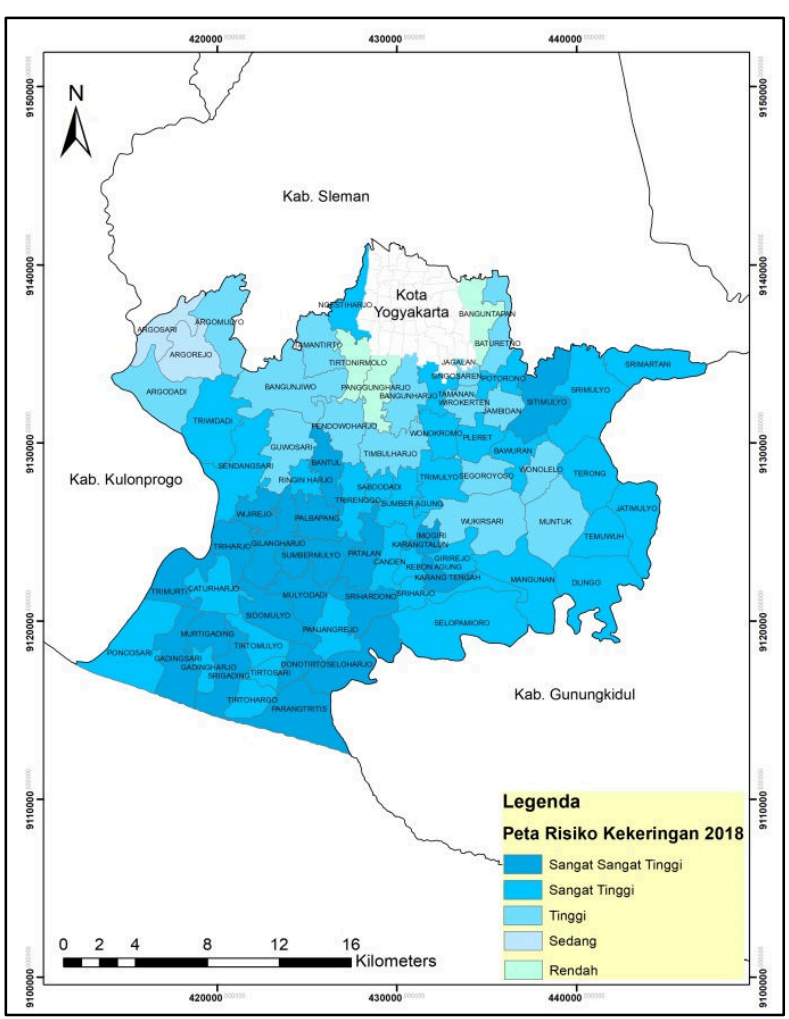

(b)

Gambar 7. Tingkat Risiko Kekeringan di Kabupaten Bantul (a) Tahun 2008 dan (b) Tahun 2018

Temuan ini mengkonfirmasi beberapa penelitian sebelumnya bahwa baik pada wilayah perkotaan dan perdesaan risiko kekeringan perlu mendapat perhatian. Hasil pemetaan risiko kekeringan secara spasial dapat menjadi masukkan bagi pemangku kepentingan untuk 
melakukan langkah mitigasi berupa manajemen sumber daya air untuk menjamin ketersediaan air di wilayah-wilayah yang rawan kekeringan (Dabanli, 2018; Nasrollahi et al., 2018).

\section{KESIMPULAN DAN SARAN}

\subsection{Kesimpulan}

Sebagian besar wilayah di Kabupaten Bantul berisiko tinggi terhadap kekeringan. Hal ini disebabkan oleh cukup tingginya tingkat ancaman bahaya kekeringan serta tingginya level kerentanan di Kabupaten Bantul. Wilayah Kabupaten Bantul bagian tengah dan selatan, baik kawasan perkotaan dan perdesaan sama-sama berisiko terhadap bahaya kekeringan. Pada wilayah perkotaan, kekeringan dipengaruhi oleh kombinasi faktor fisik dan antropogenik. Kepadatan populasi berpengaruh besar pada ketersediaan air dan berpeluang menjadi kekeringan atau kelangkaan air. Sedangkan pada wilayah perdesaan, kekeringan cenderung masih dipengaruhi oleh variabel fisik berupa kondisi curah hujan karena masih bergantungnya pada sektor pertanian. Sementara itu, jika dilihat dari kondisi kerentanan, Kabupaten Bantul memiliki Indeks Keterpaparan dan Sensitivitas (IKS) yang tinggi, namun kurang diimbangi oleh kemampuan adaptasi yang baik terutama sumber air bersih yang digunakan sehari-hari sehingga tingkat kerentanannya tinggi.

\subsection{Saran}

Penelitian ini diharapkan dapat menjadi masukkan bagi Pemerintah Kabupaten Bantul serta para pemangku kepentingan lainnya untuk dapat melakukan langkah mitigasi terhadap bahaya kekeringan di Kabupaten Bantul, baik di kawasan perkotaan dan perdesaan. Hasil analisis risiko yang ditampilkan secara spasial mempermudah untuk mengidentifikasi wilayah yang berisiko tinggi bahkan cenderung meningkat levelnya. Perlu dilakukan langkah untuk manajemen sumber daya air serta memastikan ketersediaan air.

\section{UCAPAN TERIMA KASIH}

Ucapan terima kasih penulis sampaikan kepada Direktorat Riset dan Pengabdian Masyarakat, Deputi Bidang Penguatan Riset dan Pengembangan, Kementerian Riset dan Teknologi/ Badan Riset dan Inovasi Nasional sesuai dengan Surat Perjanjian Pelaksanaan Penelitian Dosen Pemula Tahun Anggaran 2020 Nomor 081/SP2H/AMD/LT/DRPM/2020 
Tanggal 20 Mei 2020. Selain itu, penulis juga mengucapkan terima kasih kepada para asisten yang telah membantu dalam proses pengumpulan dan pengolahan data.

\section{DAFTAR PUSTAKA}

Arifin, B. (2009). Pemanasan Global dan Ketahanan Pangan Nasional. Jurnal Pangan, 55(XVIII), 3-11.

Badan Nasional Penanggulangan Bencana Indonesia. (2019). Data Informasi Bencana Indonesia (DIBI). https://bnpb.cloud/dibi/laporan5a.

Bin, H. E., Aifeng, L. Ü., Jianjun, W. U., Lin, Z., \& Ming, L. . I. U. (2011). Drought hazard assessment and spatial characteristics analysis in China. Journal of Geographical Sciences, 21(2), 235-249. https://doi.org/10.1007/s11442-011-0841-x.

BPS Kabupaten Bantul. (2018). Kabupaten Bantul Dalam Angka 2018. Badan Pusat Statistik Kabupaten Bantul.

BPS Kabupaten Bantul. (2019). Kabupaten Bantul dalam Angka 2019. BPS Kabupaten Bantul.

Christiyaningsih. (2019). BPBD: 15 Desa di Bantul Rawan Kekeringan. https://republika.co.id/berita/nasional/daerah/19/07/01/pty8e0459-bpbd-15-desa-dibantul-rawan-kekeringan.

CNN Indonesia. (2019). BMKG Prediksi Musim Kemarau 2019 Lebih Kering dari Tahun Lalu. $\quad$ https://www.cnnindonesia.com/nasional/20190704105626-20-408974/bmkgprediksi-musim-kemarau-2019-lebih-kering-dari-tahun-lalu.

Dabanli, I. (2018). Drought hazard, vulnerability, and risk assessment in Turkey. Arabian Journal of Geosciences, 11(18), 538. https://doi.org/10.1007/s12517-018-3867-x.

Dai, A. (2011). Drought under global warming: A review. Wiley Interdisciplinary Reviews: Climate Change, 2(1), 45-65. https://doi.org/10.1002/wcc.81.

Dickson, E., Baker, J. L., Hoornweg, D., \& Tiwari, A. (2012). Urban Risk Assessment Understanding Disaster and Climate Risk in Cities. Washington DC.: World Bank.

Fontaine, M. M., \& Steinemann, A. C. (2009). Assessing Vulnerability to Natural Hazards: Impact-Based Method and Application to Drought in Washington State. Natural Hazards Review, 10(1), 11-18. https://doi.org/10.1061/(ASCE)1527-6988(2009)10:1(11).

He, B., Lü, A., Wu, J., Zhao, L., \& Liu, M. (2011). Drought hazard assessment and spatial characteristics analysis in China. Journal of Geographical Sciences, 21(2), 235-249. https://doi.org/10.1007/s11442-011-0841-x.

Hisdal, H., \& Tallaksen, L. M. (2000). Drought Event Definition. In Technical Report to the ARIDE project No. 6.

Kim, H., Park, J., Yoo, J., \& Kim, T. W. (2015). Assessment of drought hazard, vulnerability, and risk: A case study foradministrative districts in South Korea. Journal of HydroEnvironment Research, 9(1), 28-35. https://doi.org/10.1016/j.jher.2013.07.003.

Li, Y., Zhang, X., Zhao, X., Ma, S., Cao, H., \& Cao, J. (2016). Assessing spatial vulnerability from rapid urbanization to inform coastal urban regional planning. Ocean and Coastal Management, 123, 53-65. https://doi.org/10.1016/j.ocecoaman.2016.01.010.

Liang, C., Li, D., Yuan, Z., Liao, Y., Nie, X., Huang, B., Wu, X., \& Xie, Z. (2019). Assessing 
urban flood and drought risks under climate change, China. Hydrological Processes, 33(9), 1349-1361. https://doi.org/10.1002/hyp.13405.

McKee, T. B., Doesken, N. J., \& Kleist, J. (1993). The Relationship of Drought Frequency and Duration to Time Scales. Eighth Conference on Applied Climatology, 17-22 Janu, 179_ 184.

Mercy Corps Indonesia. (2017). Panduan Penyusunan Kajian Risiko Iklim (Climate Risk Assessment (CRA)). Jakarta: Mercy Corps Indonesia.

Nagarajan, R. (2009). Drought Assessment. Dordrecht-Netherland: Springer.

Nam, W., Hayes, M. J., Svoboda, M. D., Tadesse, T., \& Wilhite, D. A. (2015). Drought hazard assessment in the context of climate change for South Korea. Agricultural Water Management, 160, 106-117. https://doi.org/10.1016/j.agwat.2015.06.029.

Nasrollahi, M., Khosravi, H., Moghaddamnia, A., Malekian, A., \& Shahid, S. (2018). Assessment of drought risk index using drought hazard and vulnerability indices. Arabian Journal of Geosciences, 11(20). https://doi.org/10.1007/s12517-018-3971-y.

Nuarsa, I. W., Adnyana, I. W. S., \& As-syakur, A. R. (2015). Pemetaan Daerah Rawan Kekeringan Di Bali-Nusa Tenggara Dan Hubungannya Dengan Enso Menggunakan Aplikasi Data Penginderaan Jauh. Jurnal Bumi Lestari, 15(1), 20-30.

Purnamawati, I. (2014). Analisis Rawan Kekeringan Lahan Pertanian Tanaman Pangan Dengan Memanfaatkan Citra Quickbird Dan Sistem Informasi Geografis Kabupaten Bantul Tahun 2012. Universitas Muhammadiyah Surakarta.

Rahman, M. R., \& Lateh, H. (2016). Meteorological drought in Bangladesh: assessing, analysing and hazard mapping using SPI, GIS and monthly rainfall data. Environmental Earth Sciences, 75(12), 1026. https://doi.org/10.1007/s12665-016-5829-5.

Rasch, R. J. (2015). Assessing urban vulnerability to flood hazard in Brazilian municipalities. Environment and Urbanization, 28(1), 145-168. https://doi.org/10.1177/0956247815620961.

Shahid, S., \& Behrawan, H. (2008). Drought risk assessment in the western part of Bangladesh. Natural Hazards, 46(3), 391-413. https://doi.org/10.1007/s11069-007-91915 .

Triadmodjo, B. (2008). Hidrologi Terapan. Yogyakarta: Beta Offset.

Wilhite, D. A., \& Glantz, M. H. (1985). Understanding the Drought Phenomenon: The Role of Definitions. Water International, 10(3), 111-120. https://doi.org/10.4324/9780429301735-2.

Wisner, B., Blaikie, P., Cannon, T., \& Davis, I. (2005). At Risk: Natural hazards, people's vulnerability and disasters. New York: Routledge.

Yuan, X. C., Zhou, Y. L., Jin, J. L., \& Wei, Y. M. (2013). Risk analysis for drought hazard in China: A case study in Huaibei Plain. Natural Hazards, 67(2), 879-900. https://doi.org/10.1007/s11069-013-0614-1.

Zhang, X., Chen, N., Sheng, H., Ip, C., Yang, L., Chen, Y., Sang, Z., Tadesse, T., Lim, T. P. Y., Rajabifard, A., Bueti, C., Zeng, L., Wardlow, B., Wang, S., Tang, S., Xiong, Z., Li, D., \& Niyogi, D. (2019). Urban drought challenge to 2030 sustainable development goals. Science of the Total Environment, 693, 133536. https://doi.org/10.1016/j.scitotenv.2019.07.342. 